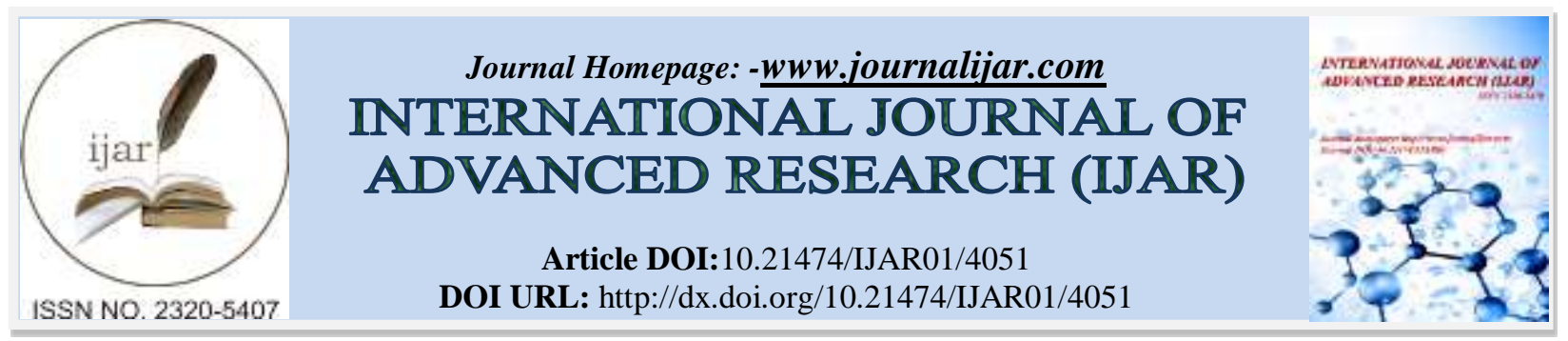

RESEARCH ARTICLE

\title{
THE EPIDEMIOLOGY AND FACTORS ASSOCIATED WITHNOCTURNAL ENURESIS AMONG SCHOOL \& PRESCHOOL CHILDREN IN HAIL CITY, SAUDI ARABIA: A CROSS-SECTIONAL STUDY.
}

\author{
Mona Madbouly Shahin ${ }^{1}$, Yasmeen Wady Zaid Al-Shamary ${ }^{2}$, Latifah Khalid Mohammad Ahrashed ${ }^{2}$, Salha \\ Saud Noor Al-Motiri ${ }^{2}$, Shahad Mohammed Awad Alhazmi ${ }^{2}$ and Waad Saud Saleh Abdulkarim Alswab ${ }^{2}$. \\ 1. Department of Pediatrics, College of Medicine, Hail University, KSA. \\ 2. College of Medicine, Hail University, KSA.
}

\section{Manuscript Info}

Manuscript History

Received: 25 February 2017

Final Accepted: 21 March 2017

Published: April 2017

Key words:-

Enuresis, nocturnal, Hail, Saudi Arabia.

\section{Abstract}

Background: Enuresis, which is frequently diagnosed amongst schoolchildren, is an important psychosocial problem for both parents and children.

Objectives: In the present study, we aimed to determine the prevalence and associated factors of enuresis in Saudi children in Hail, and to identify common methods used for its management.

Subjects and Methods: A cross sectional epidemiological study performed among children living in Hail, Saudi Arabia. A selfadministered questionnaire was prepared for this study and distributed to the parents of 700 children whom aged 5- $\neg 12$ years.

Results: Of the 700 questionnaires distributed, 652 (93.14\%) were completed.

The overall prevalence of nocturnal enuresis was $22.7 \%(\mathrm{n}=148)$. Female gender, young age, history of enuresis among parents or siblings, deep sleep and history of urinary tract infections and other social and psychological problems were associated factors with enuresis.

The percentage of children with enuresis seen by physician for treatment was $27 \%$ only. The percentage of children with enuresis treated traditionally was $40 \%$.

Conclusion: Our results with enuresis prevalence and associated factors were comparable to other epidemiologic studies from various countries.

Furthermore, we demonstrated that families in Hail do not pay sufficient attention to enuresis and most of enuretic children do not receive professional treatment.

Copy Right, IJAR, 2017,.All rights reserved.

\section{Introduction:-}

Nocturnal enuresis (NE) can be defined as the involuntary passage of urine during sleep beyond the age of anticipated nighttime bladder control, after 4-6 y of age [1,2]. It is well known that nocturnal enuresis is a common, genetically complex and heterogeneous disorder among children [3]. 
Based on the DSM-IV (diagnostic and statistical manual of mental disorders IV) criteria, enuresis refers to the urination of children over 5 years old in clothes or in bed that happens twice a week for three consecutive months can occur at night, during the day, or a combination of these two, and is also called nocturnal enuresis [4]. Enuresis is classified as primary enuresis (urinary incontinence in a child who has never been dry) and secondary enuresis (urinary incontinence in a child who has been dry for at least 6 months) [5]. Nocturnal enuresis in children is the second most common disorder after allergic diseases [6]. Nocturnal enuresis can cause a variety of behavioral, psychological, and social problems including embarrassment, blushing, lack of self-esteem, and aggression. Therefore, identifying children at risk and performing therapeutic measures are necessary $[6,5]$.

The resulting distress of the NE to children and their parents shows the public health importance of this problem, and this merits further investigation.

Healthcareprofessionals need to be able to demonstrateknowledge of the causes, assessment and management of NE to providepatients and their families with individualized care [7].

Based on the results of various investigations, enuresis has many causes including developmental differences, for example, differences in the growth of the urinary sphincters of a child, various diseases like diabetes, urinary tract infections, and so forth, emotional changes and conflicts such as the birth of a new baby and scholastic or educational stressful conditions, and emotional crises such as parental separation and divorce, family conflicts, and so forth $[5,8]$.

The overall prevalence of nocturnal enuresis, as well as prevalence of nocturnalenuresisin different age groupsis gre atlyvaried in different countries, ranging from $2.3 \%$ to $25 \%$ [3].

Our aims in this study were to determine the prevalence and associated factors of enuresis in hail children, investigate the factors its relationship with personal and family characteristics and to identify common methods of its management.

\section{Subjects and Methods:-}

The study was a community-based cross-sectional survey performed in Hail city. Hail city is one of the big cities in Saudi Arabia with around 412,758 inhabitants.

The sample size was 652 . A total 652 self-administered questionnaires were subsequently collated in an electronic format that were distributed to parents.

The questionnaires consisted of three parts. The first part contained information on socio-demographic factors such as gender, age, school performance. The second part included questions related to enuresis such as sleep pattern, social stressful events. Finally, the third part included information to assess the family-related factors.

Children were divided into three groups based on their ages as follows: group $\mathrm{A}=5-7$ years old, group $\mathrm{B}=7-10$ years old, group $\mathrm{C}=10-12$ years old. The division into the three groups was done to assess the impact of increasing age on the prevalence of nocturnal enuresis in children.

Statistical analysis:-

All the data was entered and analyzed with SPSS statistic program (statistical package for social sciences).

\section{Results:-}

A total of 700 questionnaires were administered out of which 652 questionnaires were returned giving a response rate of $93.14 \%$.

Forty-eight questionnaires were excluded because the questions unresolved and either incomplete or the data filled was inconclusive.

A total of 652 questionnaires were analyzed in the study. Of these, 286 questionnaires were answered by parents of male children while 366 were answered by parents of female children. The age of the children included in the study 
was from 5 to 12 years old .The most of the participants were between age (5-7) $41.1 \%(n=268)$, then between age $(7-10) 34.0 \%(\mathrm{n}=222)$, then between age $(10-12) 24.8 \%(\mathrm{n}=162)$ [Table1].

The overall prevalence of enuresis was $22.7 \%$.The prevalence among boys was $24.8 \%$ ( $\mathrm{n}=71$ out of 286), while it was among girls $21.0 \%$. ( $\mathrm{n}=77$ out of 366 ). The prevalence of enuresis decreased with age [Table 2] .

On exploring the characteristics of enuretic children it was noted that the rates of a positive family history for enuresis in siblings and parents were $37 \%(\mathrm{~N}=54)$ and $23.2 \%(\mathrm{~N}=34)$ respectively, the prevalence of enuresis among mothers was $14.7 \%$ while it was $9.2 \%$ among fathers. [table 3 ].

About the parents marital status, $20.2 \%$ of the parents of enuretic children were separate, while $79.8 \%$ of them are not separate [table 3].

School performance of children was excellent in $42.3 \%$, moderate in $35.3 \%$, poor in 2.5 [table 4].

Children who have deep sleep (often 51.5\%, Sometimes 40.9\%, never 7.5\%) [table4].

Children who suffer from sleep disorder: $4.1 \%$ suffer from somnambulism, $10.9 \%$ narcolepsy, $2.8 \%$ muscle contraction, $11.7 \%$ night mares, who suffer from hypersomnia $13.0 \%$, and loss of ability to sleep and insomnia $7.5 \%$ [table 4$]$.

About $12.8 \%$ of the enuretic children suffer from chronic diseases: (diabetes $2.3 \%$, hypertension $0.7 \%$, asthma $5.5 \%$ convulsion $1.4 \%$, autism $0.7 \%$, other $2.5 \%$ and who are not suffering from chronic diseases $87.2 \%$ ) [table4].

These results show whether the problem of urination resulting from complications of some prior disease (3.5\% yes, $77.0 \%$ no). [table4].

The number of times the children urinate at night (one or two times $16.3 \%$, three times $18.4 \%$, more than three times $30.7 \%$ ) [table4].

The results showed that children who are sleeping in a cold room suffer from enuresis (54.3\%) more than who sleep in the warm room (39.9\%), and also it is increase when the children watch a horror carton $28.1 \%$ [table4].

The reaction of children after woke up and they wetted themselves (Be embarrassing 59.8\%, anger 9.0, careless $26.5 \%$ ) [table4]. The mother reaction when her child wets himself (receptive $61.5 \%$, nervous $29.1 \%$, beating $4.8 \%$. [table4].

The results showed that $8.7 \%$ of children have urinary tract problems and it has been detected immediately after birth $2.9 \%$, those detected early $8.1 \%$, after long period $17.2 \%$ [table 4 ].

When we ask mothers if they know that the problem will be solved when they go to a specialist; the result was: 54.3\% they know and 39.9\% they do not know [table 5].

The results showed that $27.0 \%$ of mothers visited the doctor to solve the problem but $66.4 \%$ they did not and $40.0 \%$ of them use the traditional ways $52.8 \%$ they did not try traditional methods, then we ask if the results were satisfactory, $13.2 \%$ say it was, 42.9 say just a little bit $32.2 \%$ say it was not [table5].

About $40.5 \%$ stated that the medical methods are more effective, while $46.6 \%$ are more satisfied with the traditional methods [table 5].

\section{Discussion:-}

$\mathrm{NE}$ is recognized as a widespread health problem in young children and adolescents, but controversy exists regarding its prevalence among countries and communities. Various studies so far have used different criteria resulting in different prevalence being reported. 
When the sex differences were analyzed, nocturnal enuresis was found more in girls (24.8\%) compared with that in boys $(22.7 \%)$, and this is accordance with other studies[9,10,11,12], e.g., in Turkey,[1] India[13], but are more consistent with the findings from a study conducted in Aden (Yemen).

We found the prevalence of NE to be $22.7 \%$ in young school children and adolescents and its frequency decreases with increasing age. It is higher than that reported in other countries such as India (8.6\%)[14], Slovenia (12.4\%)[15], Australia (18.9\%) [7] And recently, in Aden (Yemen) (17.2\%)[17]. A study from Turkey, however, had prevalence of $25.5 \%$, close to the result of our study .

There are publications reporting an important relation between nocturnal enuresis and family state, history, and genetics [18,19]. In a study performed in Malaysia, positive family history was determined in $53 \%$ of the enuretic children [19]. Another study from Turkey declared that this ratio was 63 and $6 \%$ in the enuretic and control group, respectively[20]. In our study, $23.9 \%$ of the children with nocturnal enuresis were found to have positive family history in parents with higher prevalence in mothers $14.7 \%$, also $37 \%$ have positive family history in siblings. About $20.2 \%$ of cases of enuresis, parents are separated.

There have been few investigations of the severity of bedwetting in the literature. Ozden et al defined $33.3 \%$ severe enuresis as bed wetting every night in Turkish children[21]. In southeast Anatolia, the prevalence of "marked" enuresis [at least weekly] was 9.8\%[22]. In Karachi, 30\% of the children with bed wetting wet every night [23]. Wang et al found that the prevalence of bedwetting every night was $24.6 \%$ [24]. One third of the children with enuresis wet every night in our study. Our result is converged with other studies especially in Turkish study.

Our study also found a significant relationship between children who are hard to awaken and prevalence of NE, enuretic Children more likely to face difficulty in waking up than non enuretic children. Similar Sleep patterns of enuretic children were reported in other studies elsewhere [25,26]. Recent findings suggest that poor sleep quality may play a role in the continuation of NE. A vicious cycle of sleep fragmentation is suggested as a reason of an increased arousal threshold, which, in turn, leads to failure to respond to full bladder Signals and continuity of NE $[27,28,29]$.

Sleep problems and Sleep disorders,relation to these findings were consistent with a study performed in Iran and Aden [17], [30]. Enuretic children are frequently aware of the social and emotional consequences and, in particular, commonly fear being discovered by others. Systematic studies support the notification that enuresis is associated with emotional distress in both children and parents, which is reversible once the children become dry[31].These negative feelings probably could have either positive or negative influence in the school performance of children. Our study showed that school children with NE were more likely at risk of facing difficulties in their school performance. Fergusson et al and Theunis et al have reported that older enuretic children face more psychological consequences of the wetting problem and, as a result, their perceived competency decreases as their age increases. This is opposed to that seen in children without NE, in whom the perceived competency increases with age [12]. Another study has shown that girls appear more vulnerable to emotional distress, with an increased risk of being more aware of their failing body. [12]. These feelings of failure may have implications on their school performance, where success is very important. In our study we focused also on diabetes, constipation, asthma ,hypertension, autism and other diseases as major factors associated with NE, 91.7\% of the children had no associated factors and $8.0 \%$ revealed associated factors, and NE due to complications of previous cases of disease $3.5 \%$. In other studies they focused on the low birth weight, growth retardation, constipation, bronchial asthma, allergy and liquid intake before go to sleep $[31,32,33,12]$. Also hypercalcemia, decreased level of vitamin $\mathrm{B}$, migraine, habitual snoring and changes in brain microstructure have been highlighted as the possible causes for NE [34,35,36,37,38,39].

Our study focused on the frequency of wetting times per week. We found that, $4.6 \%$ urinate 3 nights per-week, and more than 3 times $1.5 \%$ and this result is consistent with a study carried out in Karachi [19] where 30\% of the NE children wet the bed every night, and in Turkish children where [1] 33.3\% of enuretics wet the bed every night. On the other hand our results are not consistent with another study which reported that $3 \%$ wet the bed more than twice a week [38].

During our research, we discovered that parents were scolding or beating their children after they discovered that they had wet themselves at night $(4.8 \%)$ or be nervous $(29.1 \%)$. This makes it worse and affects them psychologically and emotionally. 
In our study, there was an increase in nocturnal enuresis In the case of watching the child horror cartoon by $28.1 \%$, other studies have shown children with nocturnal enuresis had experienced a frightening event and $44.7 \%$ of them had emotional stress (sudden death, birth of new sibling, separation etc.) before the beginning of bedwetting.

Many children with enuresis had a history of daytime incontinence (inability to control urine) and urinary tract infection. No further information was obtained in this regard. A linear relationship between enuresis and the frequency of urinary tract infection has been noted in the past. There have been recent reports of enterobiasis infection in children with enuresis being the sole symptom at presentation [40].

Also this result correlates with other studies [41,42] which confirmed that UTI is more strongly connected with secondary nocturnal enuresis and with day time wetting. Less than $5 \%$ of all bedwetting cases are caused by infection or disease, the most common of which is the urinary tract infection.

During the study, 54.3\% Parents were found to have knowledge that the nocturnal enuresis would be resolved if they asked for physician help, however only $27.0 \%$ of the children were seen by a physician and previous series reported as 53.8\%[44,11,45] these low rates demonstrate that most of the children with enuresis were not treated.40\% used traditional methods and showed that traditional methods were $13.2 \%$ effective, the study showed that the traditional method its effect is better and faster than the medical method by $46.6 \%$. Children with enuresis had a history of daytime incontinence (inability to control urine) and urinary tract infection. No further information was obtained in this regard. A linear relationship between enuresis and the frequency of urinary tract infection has been noted in the past. There have been recent reports of enterobiasis infection in children with enuresis being the sole symptom at presentation.

Other studies confirmed that UTI is more strongly connected with secondary nocturnal enuresis and with daytime wetting. Less than $5 \%$ of all bedwetting cases caused by infection or disease, the most common of which is the urinary tract infection.

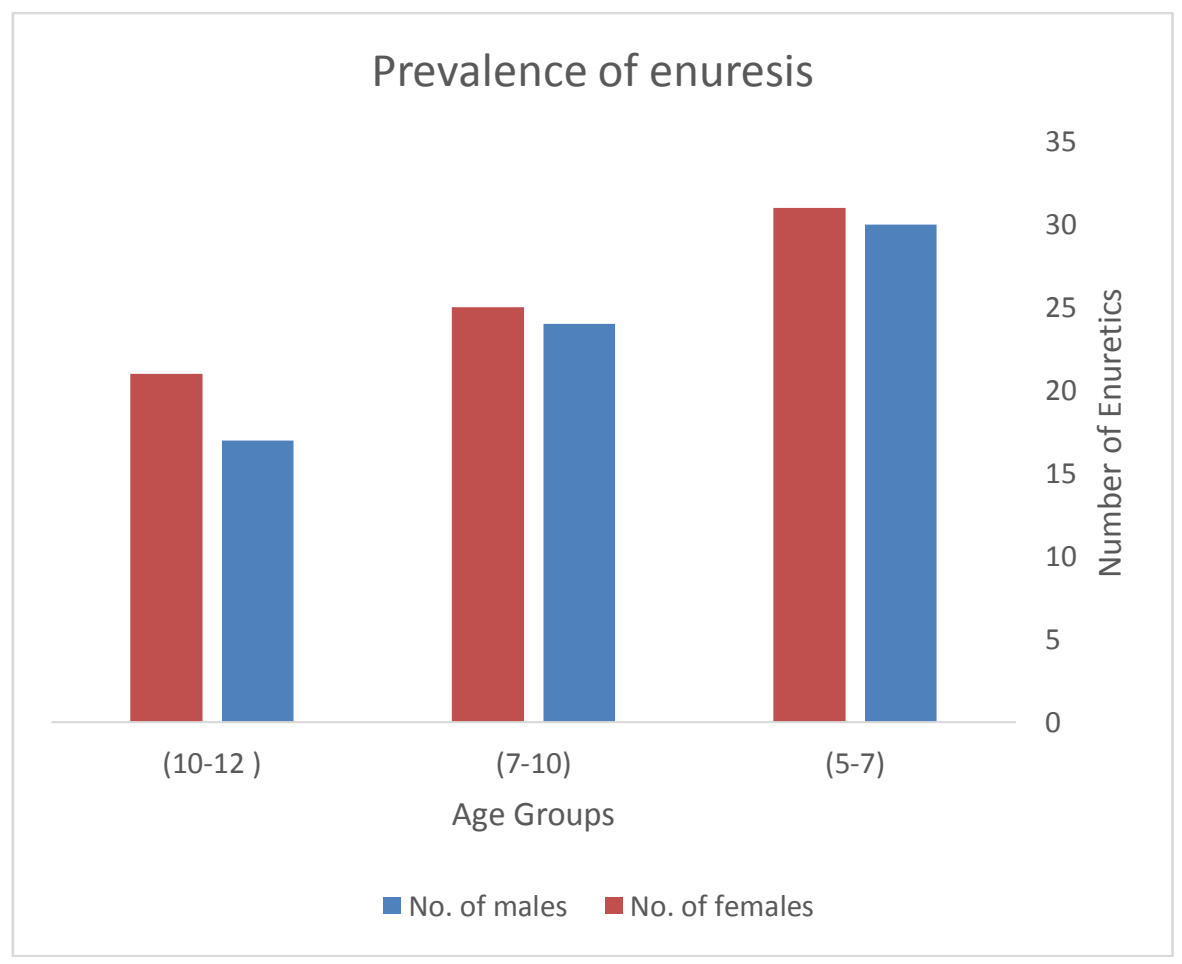




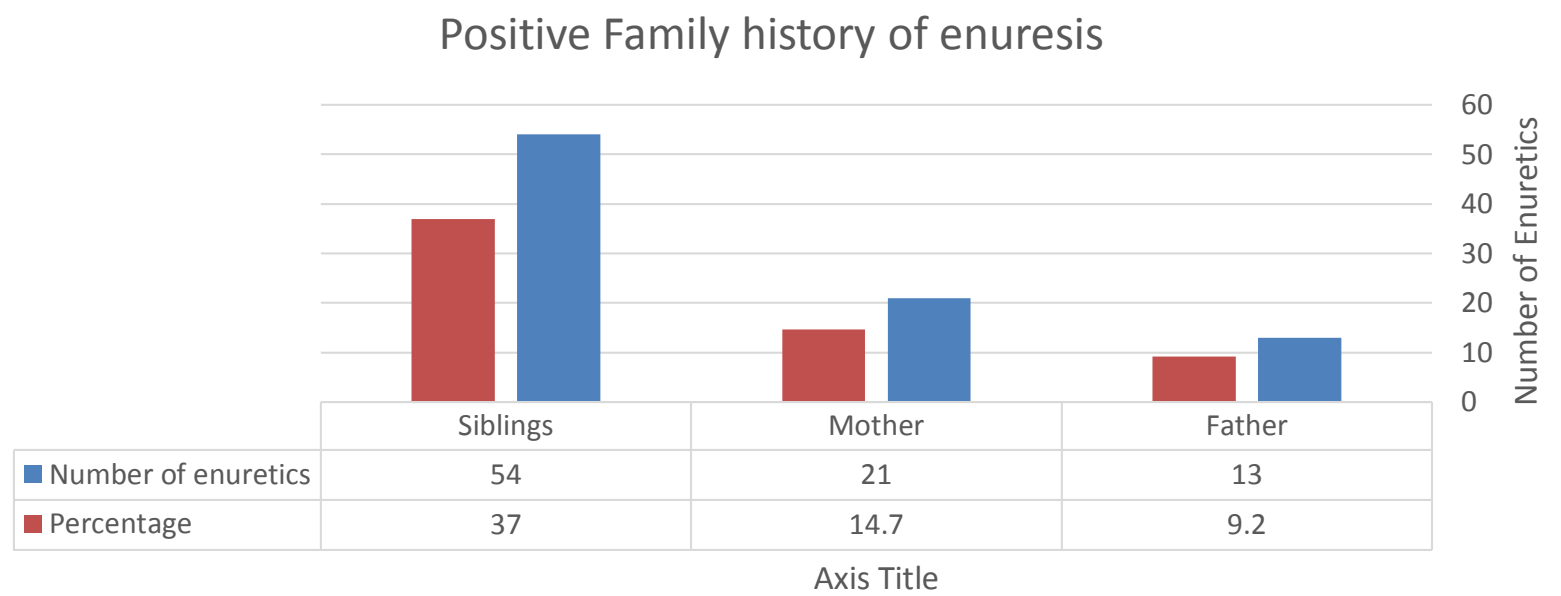

Prevelance of primary $\&$ secondary enuresis

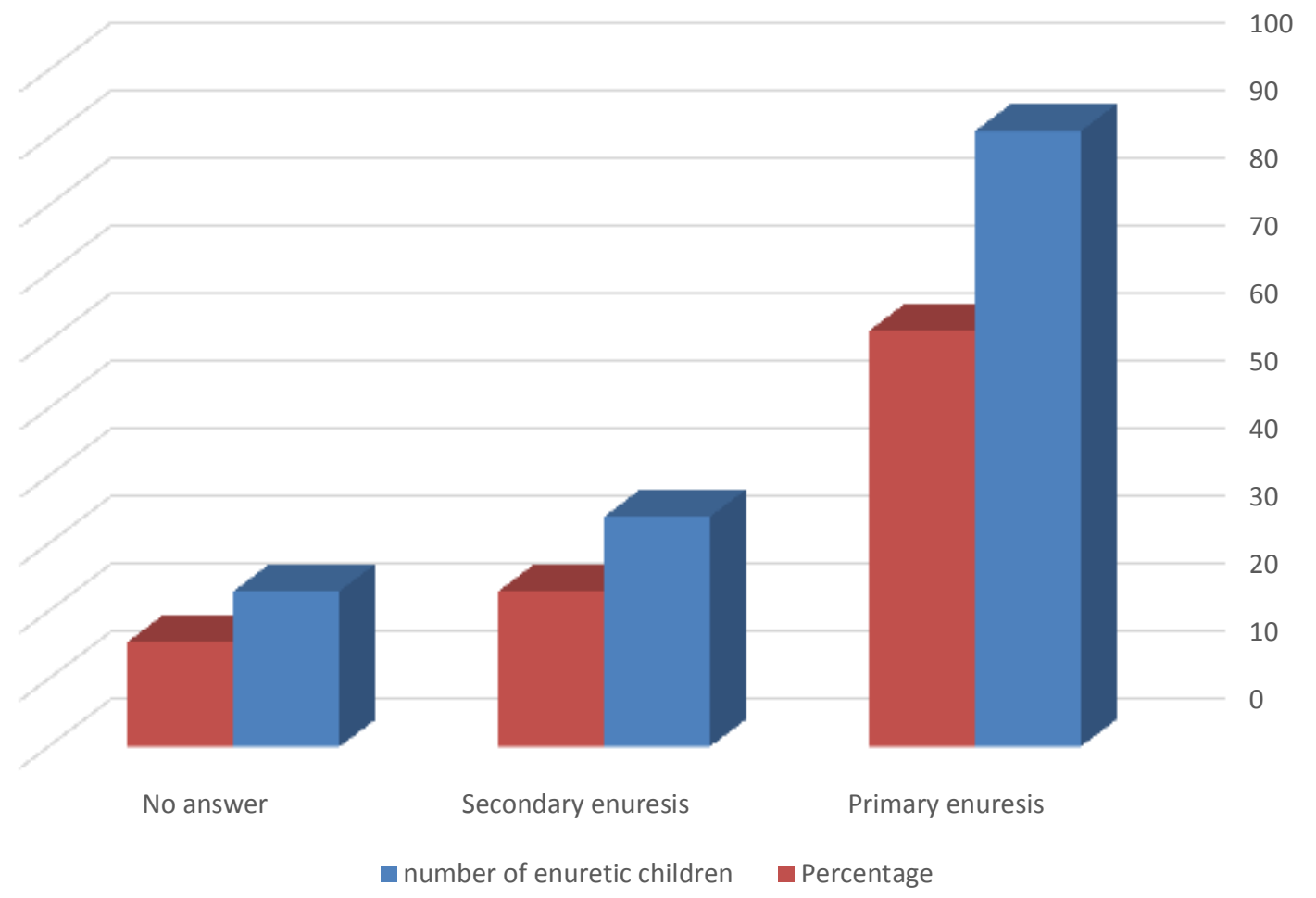



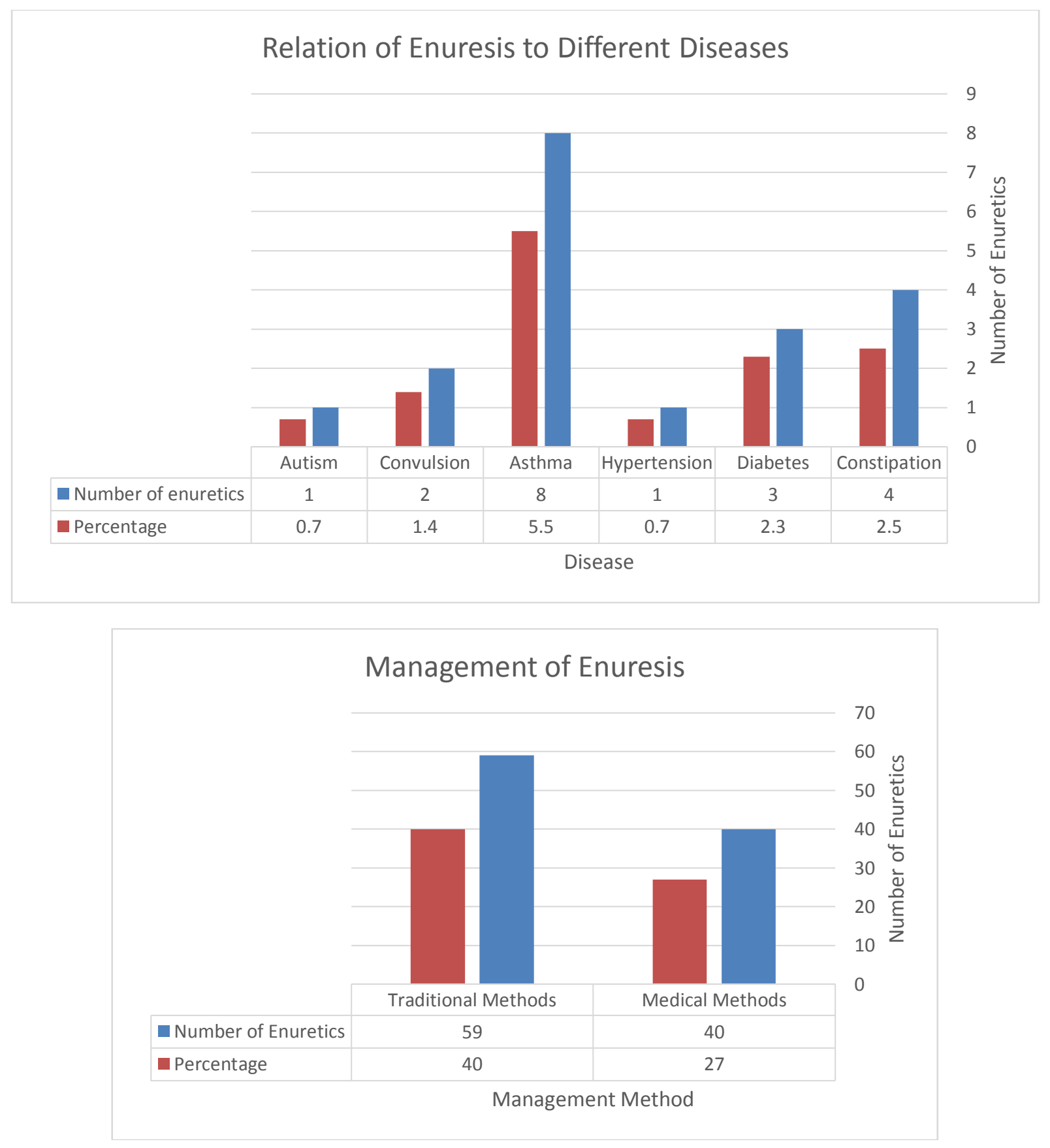

Table 1:-Gender and age distribution of children.

\begin{tabular}{|l|l|l|}
\hline Data & No. of children & Percentage \\
\hline Male & 286 & 43.9 \\
\hline Female & 365 & 56.0 \\
\hline Age(5-7) & 268 & 41.1 \\
\hline Age(7-10) & 222 & 34.0 \\
\hline Age(10-12) & 162 & 24.8 \\
\hline
\end{tabular}


Table 2:-Prevalence of enuresis

\begin{tabular}{|l|l|l|l|l|l|}
\hline & Data & No. of children & Percentage & No. of males & No. of females \\
\hline \multirow{5}{*}{ Eneuretics } & $(5-7)$ & 268 & $41.1 \%$ & 30 & 31 \\
\cline { 2 - 6 } & $(7-10)$ & 222 & $34.0 \%$ & 24 & 25 \\
\cline { 2 - 6 } & $(10-12)$ & 162 & $24.8 \%$ & 17 & 21 \\
\hline \multirow{2}{*}{ Total } & & 652 & $100 \%$ & $\mathbf{7 1}$ & $\begin{array}{l}\mathbf{7 7} \\
(24.8 \%)\end{array}$ \\
\hline
\end{tabular}

Table 3:-Family history of enuresis

\begin{tabular}{|l|l|l|l|}
\hline Data & & No. & Percentage \\
\hline Parents state & Separate & 30 & 20.2 \\
\cline { 2 - 4 } & not separate & 118 & 79.8 \\
\hline \multirow{2}{*}{ History of Nocturnal Enuresis in Parents } & Yes & 34 & 23.9 \\
\cline { 2 - 4 } & No & 79 & 53.5 \\
\hline \multirow{2}{*}{ Which One? } & Father & 13 & 9.2 \\
\cline { 2 - 4 } & Mother & 21 & 14.7 \\
\hline History of Nocturnal Enuresis in Siblings & Yes & 54 & 37.0 \\
\cline { 2 - 4 } & No & 88 & 59.4 \\
\hline
\end{tabular}

Table 4:-Characteristics of the enuretic children

\begin{tabular}{|c|c|c|c|}
\hline Data & & $\mathbf{N}$ & percentage \\
\hline \multirow[t]{3}{*}{ School performance } & Excellent & 78 & 42.3 \\
\hline & Moderate & 60 & 35.3 \\
\hline & Poor & 10 & 2.5 \\
\hline \multirow[t]{3}{*}{ Does the child have deep sleep } & usually & 76 & 51.5 \\
\hline & sometimes & 60 & 40.9 \\
\hline & never & 12 & 7.5 \\
\hline \multirow[t]{6}{*}{ Sleep problem } & insomnia & 11 & 7.5 \\
\hline & hypersomnia & 19 & 13.0 \\
\hline & somnambulism & 6 & 4.1 \\
\hline & narcolepsy & 16 & 10.9 \\
\hline & muscle contraction & 4 & 2.8 \\
\hline & night mares & 17 & 11.7 \\
\hline \multirow[t]{2}{*}{ Chronic diseases } & Yes & 13 & 8.0 \\
\hline & No & 135 & 91.7 \\
\hline \multirow[t]{6}{*}{ What is the disease? } & diabetes & 3 & 2.3 \\
\hline & Constipation & 4 & 3.5 \\
\hline & asthma & 8 & 5.5 \\
\hline & convulsion & 2 & 1.4 \\
\hline & hypertension & 1 & 0.7 \\
\hline & autism & 1 & 0.7 \\
\hline \multirow[t]{2}{*}{ Complications from previous illness } & Yes & 5 & 3.5 \\
\hline & No & 113 & 77.0 \\
\hline \multirow{3}{*}{$\begin{array}{l}\text { Did the child have been dry before for at least } 6 \\
\text { months? }\end{array}$} & yes & 34 & 22.97 \\
\hline & No & 91 & 61.5 \\
\hline & No answer & 23 & 15.5 \\
\hline \multirow[t]{3}{*}{ How many times of bedwetting per week? } & $1-3$ & 51 & 34.5 \\
\hline & $>3$ & 45 & 30.7 \\
\hline & No answer & 51 & 34.7 \\
\hline \multirow[t]{4}{*}{ Child reaction } & embarrassing & 88 & 59.8 \\
\hline & anger & 13 & 9.0 \\
\hline & Indifference & 39 & 26.5 \\
\hline & No answer & 7 & 4.6 \\
\hline \multirow[t]{3}{*}{ Problem increase in } & horror carton & 41 & 28.1 \\
\hline & others & 52 & 35.3 \\
\hline & no answer & 11 & 8.1 \\
\hline
\end{tabular}




\begin{tabular}{|l|l|l|l|}
\hline \multirow{4}{*}{ Mother reaction } & receptive & 91 & 61.5 \\
\cline { 2 - 4 } & nervous & 43 & 29.1 \\
\cline { 2 - 4 } & beating & 7 & 4.8 \\
\cline { 2 - 4 } & no answer & 7 & 4.8 \\
\hline \multirow{5}{*}{ Urinary problems } & Yes & 14 & 8.7 \\
\cline { 2 - 4 } & No & 131 & 89.1 \\
\cline { 2 - 4 } & no answer & 3 & 2.1 \\
\hline When detected and treated? & immediately after birth & 4 & 2.9 \\
\cline { 2 - 3 } & Early & 12 & 8.1 \\
\cline { 2 - 3 } & after a long period & 26 & 17.8 \\
\cline { 2 - 3 } & no answer & 105 & 71.2 \\
\hline
\end{tabular}

Table5:-Management of enuresis

\begin{tabular}{|c|c|c|c|}
\hline Data & & No. & Percentage \\
\hline \multirow{3}{*}{$\begin{array}{l}\text { Did you know that the problem can be solved by } \\
\text { doctor? }\end{array}$} & Yes & 80 & 54.3 \\
\hline & No & 59 & 39.9 \\
\hline & no answer & 9 & 5.8 \\
\hline \multirow[t]{3}{*}{ Did you ask for medical advice to solve this problem? } & Yes & 40 & 27.0 \\
\hline & No & 98 & 66.4 \\
\hline & no answer & 9 & 6.4 \\
\hline \multirow[t]{3}{*}{ Did you use traditional methods for management? } & Yes & 59 & 40.0 \\
\hline & No & 77 & 52.8 \\
\hline & no answer & 9 & 6.5 \\
\hline \multirow[t]{4}{*}{ Did you have satisfactory results? } & Yes & 19 & 13.2 \\
\hline & Little bit & 63 & 42.9 \\
\hline & No & 47 & 32.2 \\
\hline & no answer & 17 & 11.7 \\
\hline \multirow{3}{*}{$\begin{array}{l}\text { Which was more beneficial, medical or traditional } \\
\text { methods? }\end{array}$} & Medical & 60 & 40.5 \\
\hline & traditional & 69 & 46.6 \\
\hline & no answer & 18 & 12.7 \\
\hline
\end{tabular}

\section{Conclusion:-}

Nocturnal enuresis is a pediatric public health problem that is associated with young age, low socioeconomic factors, low educational level of parents, deep sleep, family history of nocturnal enuresis, history of urinary tract infection and psychological problems. We documented that most of the children with enuresis were not treated and the families in Hail city do not have adequate attention about enuresis.

\section{Recommendations:-}

$\mathrm{NE}$ in children is an alarming complaint that needs proper evaluation and proper management. Programs for raising parent awareness regarding nocturnal enuresis. Routine medical examination and laboratory investigations of children for early evaluation of the problem and proper treatment of such cases. Parent's reaction toward the child should be supportive and encouraging him to pass this problem.

\section{References:-}

1. Ozden C, Ozdal OL, Altinova S, Oguzulgen I, Urgancioglu G, Memis A: Prevalence and associatedfactors of en uresis in Turkish children. Int Braz J Urol. 2007, 33 (2): 216-22. 10.1590/S167755382007000200013.

2. Gumus B, Vurgun N, Lekili M, Işcan A, Muezzinoglu T, Buyuksu C: Prevalence of nocturnal enuresis andacco mpanying factors in children aged 7-11 years in Turkey.

3. Acta Paediatr. 1999, 88: 1369-72.10.1080/080352599750030103.

4. Wen JG, Wang QW, Chen Y, Wen JJ, Liu K: An epidemiological study of primary nocturnal enuresis inChinese children and adolescents. Eur Urol. 2006, 49 (6): 1107-13. 10.1016/j.eururo.2005. 11.011.

5. S. Özkan, E. Durukan, E. Iseri, S. Gürocak, I. Maral, and M. A. Bumin, "Prevalence and risk factors of monosymptomatic nocturnal enuresis in Turkish children," Indian Journal of Urology, vol. 26, no. 2, pp. 200205, 2010. View at Publisher · View at Google Scholar · View at Scopus 
6. N. Ghotbi and G. H. Kheirabadi, "Prevalence of nocturia and its associated factors in primary school children in Sanandaj in 2002," Journal of Kurdistan University of Medical Sciences, vol. 5, no. 20, pp. 30-33, 2001. View at Google Scholar.

7. E. Gür, P. Turhan, G. Can, et al., "Enuresis: prevalence, risk factors and urinary pathology among school children in Istanbul, Turkey," Pediatrics International, vol. 46, no. 1, pp. 58-63, 2004. View at Publisher · View at Google Scholar · View at Scopus

8. Yousef KA, Basaleem HO, bin Yahiya MT. Epidemiology of nocturnal enuresis in basic schoolchildren in Ade nGovernorate, Yemen. Saudi J Kidney Dis Transpl 2011;22:167-73

9. E. R. Behrman, M. R. Kliegman, and B. H. Jenson, Nelson Textbook of Pediatrics, Saunders, Philadelphia, Pa, USA, 18th edition, 2007.

10. Gontard A, Benden B, MauerMucke K, Lehmkuhl G. Somatic correlates of functional enuresis. Eur Child Adoles Psychiatry. 1999;8:117-25. [PubMed]

11. Gümüş B, Vurgun N, Lekili M, Işçan A, Müezzinoğlu T, Büyüksu C. Prevalence of nocturnal enuresis and accompanying factors in children aged 711 years in Turkey. ActaPaediatr. 1999;88:1369-72. [PubMed]

12. Oge O, Kocak I, Gemalmaz H. Enuresis: Point prevalence and associated factors among: Turkish children. Turk J Pediatr. 2001;43:38-43. [PubMed]

13. Cher TW, Lin GJ, Hsu KH. Prevalence of nocturnal enuresis and associated familial factors in primary school children in Taiwan. J Urol. 2002;168:1142-6. [PubMed]

14. Mithani S, Zaidi Z. Bed wetting in school children of Karachi. J Pak Med Assoc 2005;55: 25.

15. Karnicnik K, Koren A, Kos N, MarcunVarda N. Prevalence and quality of life of slovenian children with primary nocturnal enuresis. Int J Nephrol 2012;2012:509012.

16. Bower WF, Moore KH, Shepherd RB, Adams RD. The epidemiology of childhood enuresis in Australia. Br JUrol 1996;78:6026.

17. Gontard von A, Schamburg H, Hollmann E, Eiberg H, Rittig S. The genetics of enuresis: A review. J Urol.2001;166:2438-43. [PubMed]

18. Kanaheswari Y. Epidemiology of childhood nocturnal enuresis in Malaysia. J Pediatr Child Health.2003;39:118-23. [PubMed]

19. Turgut F, Aksoy L, Özsoylu S. Familial inheritance of nocturnal enuresis. N J Med. 2001;18:61-3.

20. Ozkan KU, Garipardic M, Toktamis A, Karabiber H, Sahinkanat T: Enuresis prevalence and accompanying factors in schoolchildren: A questionnaire study from southeast Anatolia. Urol Int. 2004,73: 14955.10.1159/000079696.

21. Wang QW, Wen JG, Song DK, Su J, Zhu QH, Liu K, Che YY, Du AM, Wei JX: Bedwetting in Chinese children: epidemiology and predictive factors. NeurourolUrodyn. 2007, 26 (4): 5127. 10.1002/nau.20373.

22. Byrd RS, Weitzman M, Lanphear NE, Auinger P. Bedwetting in US children: Epidemiology and related behavior problems. Pediatrics 1996;98:4149.

23. Aloni MN, Ekila MB, Ekulu PM, Aloni ML, Magoga K. Nocturnal enuresis in children in Kinshasa, Democratic Republic of Congo. ActaPaediatr 2012;101:e4758.

24. eung CK, Sihoe JD, Sit FK, Bower W, Sreedhar B, Lau J. Characteristics of primary nocturnal enuresis in adults: An epidemiological study. BJU Int 2004;93:3415.

25. Joinson C, Heron J, Emond A, Butler R. Psychological problems in children with bedwetting and combined (day and night) wetting: A UK populationbased study. J PediatrPsychol 2007;32:60516.

26. Fergusson DM, Horwood LJ. Nocturnal enuresis and behavioral problems in adolescence: A 15year longitudinal study. Pediatrics 1994; 94:6628.

27. Theunis M, Van Hoecke E, Paesbrugge S, Hoebeke P, VandeWalle J. Selfimage and performance in children with nocturnal enuresis. EurUrol 2002;41:6607.

28. Butler R, Heron J. An exploration of children's views of bedwetting at 9 years. Child Care Health Dev2008;34:6570.

29. Ozkan S, Durukan E, Iseri E, Gurocak S, Maral I, Ali Bumin M. Prevalence and risk factors of monosymptomatic nocturnal enuresis in Turkish children. Indian J Urol 2010; 26:2005. [PUBMED]

30. Hanafin S. Sociodemographic factors associated with nocturnal enuresis. Br J Nurs 1998; 7:4038.

31. Mansour A, Saad K, Molokhia T. Evaluation of impact of enuresis on quality of parental reaction towards their enuretic children: A comparison of mothers with fathers. Egypt J Psychiatry 2009;29:6570.

32. Kalo BB, Bella H: Enuresis: prevalence and associated factors among primary school children in Saudi Arabia. ActaPaediatr. 1996; 85: 121722. [ Links ]

33. Chang P, Chen WJ, Tsai WY, Chiu YN: An epidemiological study of nocturnal enuresis in Taiwanese children. BJU Int. 2001; 87: 67881. [ Links ] 
34. Rawashdeh YF, Hvistendahl GM, Kamperis K, Hansen MN, Djurhuus JC: Demographics of enuresis patients attending a referral centre. Scand J UrolNephrol. 2002; 36: 34853. [ Links ]

35. Lei D, Ma J, Shen X, et al. Changes in the brain microstructure of children with primary monosymptomatic nocturnal enuresis: A diffusion tensor imaging study. PLoS One 2012;7:e31023.

36. Altunoluk B, Davutoglu M, Garipardic M, Bakan V. Decreased vitamin B12 levels in children with nocturnal enuresis. ISRN Urol 2012;2012:789706.

37. Kim JM. Diagnostic value of functional bladder capacity, urine osmolality, and daytime storage symptoms for severity of nocturnal enuresis. Korean J Urol 2012;53:1149.

38. Lin J, Rodrigues Masruha M, Prieto Peres MF, et al. Nocturnal enuresis antecedent is common in adolescents with migraine. EurNeurol 2012;67:3549.

39. Nikibakhsh A, Poostindooz H, Mahmoodzadeh H, Karamyyar M, Ghareaghaji RR, Sepehrvand N. Is there any correlation between hypercalciuria and nocturnal enuresis? Indian J Nephrol 2012;22:8893.[PUBMED]

40. Sakellaropoulou AV, Hatzistilianou MN, Emporiadou MN, et al. Association between primary nocturnal enuresis and habitual snoring in children with obstructive sleep apnoeahypopnoea syndrome. Arch Med Sci 2012; 8:5217.

41. Carol J, Jon H, Alan E, Richard B. Psychological problems in children with bedwetting and combined (day and night) wetting: a UK population-based study. J PediatrPsychol 2010;32(5):605-16.

42. Von Gontard A, Benden B, MauerMucke K, Lehmkuhl G. Somatic correlates of functional enuresis. Eur Child Adolesc Psychiatry. 1999;8:117-25. [PubMed]

43. Von Gontard A, Schaumburg H, Hollmann E, Eiberg H, Rittig S. The genetics of enuresis: a review. J Urol 2001;166(6):2438-43.

44. Franklin EK, Nenad D, Markus H. Infantile enuresis: current state-of-the-art therapy and future trends. Rev Urol 2011;13(1):1-6.

45. Lee SD, Sohn DW, Lee JZ, Park NC, Chung MK: An epidemiological study of enuresis in Korean children. BJU Int. 2000; 85: 86973. [ Links ]

46. Serel TA, Akhan G, Koyuncuoglu HR, Ozturk A, Dogruer K, Unal S, et al.: Epidemiology of enuresis in Turkish children. Scand J UrolNephrol. 1997; 31: 5379 [ Links ]. 